УДК 664.8.036.53.001.76

\title{
IMPROVEMENT OF THE PROCESS PRODUCTION OF VEGETABLE CONVENIENCE FOODS FROM FRUIT-AND- BERRY RAW MATERIALS OF GUARANTEED QUALITY
}

\author{
O. Cherevko, V. Mykhaylov, A. Zagorulko, A. Zahorulko \\ Kharkiv State University of Food Technology and Trade
}

\begin{tabular}{l}
$\quad$ Key words: \\
Fruit and berry raw \\
materials \\
Digital processing \\
Color \\
CIE XYZ system \\
Dominant wavelength \\
Color purity \\
Brightness \\
Concentration \\
IR drying \\
\hline
\end{tabular}

Article history:

Received 10.09.2018

Received in revised form

02.10 .2018

Accepted 23.10.2018

Corresponding author:

O. Cherevko

E-mail:

npnuht@ukr.net

\begin{abstract}
The method for the production of multicomponent semifinished products from fruit and berry raw materials is developed. The use of an advanced rotary film apparatus (RFA) and a roller IR dryer based on a flexible film resistive electric heater of radiant type (FFREHofRT) for the processes of concentration and drying, differs this method from the others. Rational regimes for processing of plant raw materials for the developed equipment are determined. The developed method for assessing the quality of the obtained semi-finished products with different prescription composition (apple, cranberry, hawthorn) has been approbated. The quality assessment was carried out through the research of color characteristics by spectroscopy and developed by the digital processing method. The color of the test specimens during spectroscopy was evaluated using color parameters in the CIE XYZ system (dominant wavelength $(\lambda \mathrm{d}, \mathrm{nm})$, brightness $(T, \%)$, color purity $(P, \%))$. It is established that the differences in the results of the comparative analysis of color parameters of the experimental samples obtained during the spectral analysis and the proposed digital method make up less than $5 \%$, which is within the limits of the experimental error. This confirms the effectiveness of using the digital color analysis method during any technological process available for taking photographs. At the same time, the proposed method of digital color analysis not only for fruit and for berry compositions, but also for food products in general, provides mobility and portability of the analysis with short-term processing of the received digital data and simultaneous presentation of the results in qualitative color parameters. An assessment of the quality of dried multicomponent fruit and berry pastes established the advantage of the sample with such percentage ratio of components: apple, cranberry, hawthorn - 60:30:10.
\end{abstract}

DOI: $10.24263 / 2225-2924-2018-24-5-19$ 


\title{
УДОСКОНАЛЕННЯ СПОСОБУ ВИРОБНИЦТВА НАПІВФАБРИКАТІВ 3 ПЛОДОВО-ЯГІДНОЇ СИРОВИНИ ГАРАНТОВАНОÏ ЯКОСТ।
}

\author{
О.І. Черевко, В.М. Михайлов, О.Є. Загорулько, А.М. Загорулько \\ Харківський державний університет харчування та торгівлі
}

У статті описано спосіб виробництва багатокомпонентних напівфабрикатів з плодово-ягідної сировини. Спосіб відрізняється тим, що для процесів концентрування та сушіння використовується удосконалений роторний плівковий апарат (РПА) та вальцьова ІЧ-сушарка на основі гнучкого плівкового резистивного електронагрівача випромінюючого типу (ГПРЕнВТ). Для розробленого обладнання встановлені раціональні режими обробки рослинної сировини. Проведено апробацію розробленого способу для оиінки якості отриманих напівфабрикатів за різним рецептурним складом (яблуко, журавлина, глід). Оиінку якості проведено дослідженням кольорових характеристик методом спектроскопії та розробленим методом ичиррової обробки. Колір дослідних зразків під час спектроскопії оцінювався за допомогою параметрів кольору у системі СІЕ XYZ (домінуюча довжина хвилі (入дом, нм), яскравість (T, \%), чистота кольору (P, \%)). Встановлено, щзо розбіжності результатів порівняльного аналізування кольорових параметрів дослідних зразків, отриманих під час спектрального аналізу, та запропонованого цифрового методу становлять менше 5\%, що є в межах експериментальної похибки. Це підтверджує подальшу ефективність використання иифрового методу аналізу кольорових характеристик під час будь-якого доступного для фотографування технологічного процесу. При изьму запропонований метод цифрового аналізування кольору не лише для плодово-ягідних композицій, а й харчових продуктів у иілому забезпечуе мобільність $i$ портативність аналізування з короткотривалою обробкою отриманих цифрових даних та одночасного представлення отриманих результатів в якісні кольорові параметри. Оиінкою якості сушених багатокомпонентних плодово-ягідних паст встановлено перевагу зразка із таким відсотковим співвідношення компонентів: яблуко, журавлина, глід - 60:30:10.

Ключові слова: плодово-ягідна сировина, иифрова обробка, колір, система CIE XYZ, домінуюча довжина хвилі, чистота кольору, яскравість, конщентрування, ІЧ-сушіння.

Постановка проблеми. Під час виробництва харчових продуктів природного походження необхідно досягати максимального збереження біологічно активних речовин (БАР) та високої якості на всіх технологічних стадіях обробки. Для збереження початкових властивостей рослинної сировини під час виробництва порошкоподібних напівфабрикатів використовують попередньо концентровані багатокомпонентні плодово-ягідні пасти 3 подальшим їх висушуванням. 
Виробництво комбінованих харчових продуктів на основі сушених багатокомпонентних плодово-ягідних паст забезпечить розширення асортименту продукції природного походження із підвищеним вмістом харчової цінності та лікувальнопрофілактичними властивостями, необхідними для щоденного споживання.

Одним 3 визначальних показників якості харчових продуктів з рослинної сировини є колір і ступінь його збереження під час тепловій обробці. Отримання привабливого кольору для споживача можливо досягти за рахунок комбінування різних видів рослинної сировини із високим вмістом БАР та енергетичною цінністю. Все це обумовлює актуальність досліджень кольороутворення в процесі виробництва сушених багатокомпонентних плодовоягідних напівфабрикатів на основі плодово-ягідних паст із використанням сприятливих температурних режимів обробки [1].

Аналіз останніх досліджень і публікацій. Під час виробництва сушених природних напівфабрикатів, як правило, не намагаються штучно збільшувати вміст БАР та підвішувати енергетичну цінність отримуваної продукції. Але вирішення цього недоліку $є$ нескладним технологічним завданням, яке вирішується комбінуванням різної за вмістом БАР природної сировини в композиції. При цьому необхідно враховувати мікробіологічний склад кожного компонента, його кислотність і насиченість кольороутворювальним пігментом.

Найбільш простим рішенням під час виробництва сушених багатокомпонентних плодово-ягідних напівфабрикатів $є$ модернізація технологічних ліній концентрування, оскільки саме попередньо концентрований напівфабрикат, наприклад, пасту, доцільніше досушувати в прийнятних теплових режимах із одночасним знезаражуванням до порошкоподібного стану. Це, у свою чергу, забезпечить не лише розширення асортименту сушеної продукції 3 високим вмістом БАР порівняно з початковою рослинною сировиною, а й дасть змогу економити на іiі транспортуванні та зберіганні. Проте виникає апаратурна проблема, пов'язана з невеликою кількості ефективних сушарок, призначених для сушіння паст з одночасним їх знезаражуванням, безпосередньо ІЧ-сушарок [2].

Під час виробництва сушених багатокомпонентних плодово-ягідних паст актуальним завданням $\epsilon$ об'єктивне визначення кольороутворювальних властивостей у композиціях під час виконання технологічних операцій та впливу їх на загальний показник якості [3].

У багатьох технологіях виготовлення сушених плодово-ягідних порошків значна увага приділяється інноваційним ресурсозберігаючим технологіям, але щоденний їх розвиток і вдосконалення техніки обумовлює необхідність у використанні сучасних технологій за умов, що єдиного підходу до виготовлення сушених напівфабрикатів ще не існує. Також на сьогодні гостро стоїть питання забезпечення населення високоякісними природними напівфабрикатами зі штучним їх збагаченням вітамінами та лікувально-профілактичними властивостями. Це досягається шляхом поєднання певної кількості різновидів природної сировини в композиції, яка потребує детального дослідження стосовно отриманої якості та принципів змін кольороутворення при їх змішуванні [3]. В багатьох випадках при купажуванні намагаються не лише штучним шляхом збільшувати природний вміст вітамінів у компо- 
зиціях, а й отримувати привабливий для споживача колір. Тому виникає потреба в пошуках сучасних інноваційних і простих методів 3 визначення зміні кольороутворення в отримуваних композиціях на всіх стадіях їх виготовлення. Дослідження змін кольороутворення, як і техніка й технологія, не мають єдиного шляху реалізації та постійно змінюються з розвитком наукового прогресу. Саме тому у дослідженні пропонується вирішення вищезазначених існуючих проблем при виробництві купажованих сушених багатокомпонентних плодово-ягідних паст з використанням сучасних інноваційних ІЧ-сушарок і визначенням змін кольороутворення отримуваних композицій залежно від частки масового вмісту кожного компонента в композиції.

Отримані дані дадуть змогу оптимізувати технологічні параметри переробки природної сировини, визначити колір продукції з урахуванням рецептури композицій та забезпечити гарантовану якість харчових продуктів на iii основі з привабливим для споживача кольором.

Мета дослідження: розробка способу виробництва багатокомпонентних напівфабрикатів 3 плодово-ягідної сировини гарантованої якості та визначення їх кольорових та органолептичних характеристик на різних стадіях виробництва.

Викладення основних результатів дослідження. Для розробленого способу виробництва напівфабрикатів 3 плодово-ягідної сировини як показник якісної оцінки отриманих багатокомпонентних композицій на різних стадіях виробництва, а саме пюре, пасти та сушені порошкоподібні вироби, було обрано їх колір. Колір - це перша ознака якості і свіжості продукції, а взаємозв'язок якості й кольору особливо проявляється для продуктів рослинного походження, оскільки це обумовлено тісною кореляцією між кольором і вмістом барвних речовин (хлорофілів, каротиноїдів і речовин фенольної природи).

Оцінку кольорових характеристик проводили методом спектроскопії та розробленим методом цифрової обробки. Такий підхід застосували для порівняння отриманих результатів спектроскопії й цифрової обробки, щоб підтвердити ефективність використання та достовірності отриманих результатів при застосуванні розробленого цифрового методу [4]. Під час апробації методу цифрової обробки дослідні зразки плодово-ягідної сировини рівномірно наносили на дослідницьке дзеркальце товщиною шару 0,5 мм та здійснювали цифрове фотографування з подальшим комп'ютерним аналізуванням знімка в Міжнародній системі координат CIE. Також з метою апробації вдосконаленого РПА та розробленої вальцьової ІЧ-сушарки на основі гнучкого плівкового резистивного електронагрівача випромінюючого типу (ГПРЕнВТ) [5; 6] запропоновано рецептурне співвідношення плодово-ягідних компонентів у багатокомпонентних композиціях, наведених у табл. 1.

Таблиця 1. Рецептурне співвідношення природних компонентів у багатокомпонентних композиціях

\begin{tabular}{|c|c|c|c|}
\hline \multirow{2}{*}{ Компонентний склад } & \multicolumn{3}{|c|}{ Композиція (зразок) } \\
\cline { 2 - 4 } & $1 \mathrm{a}$ & 16 & 1 в \\
\hline Яблуко & 60 & 65 & 55 \\
\hline Журавлина & 30 & 25 & 40 \\
\hline Глід & 10 & 10 & 5 \\
\hline Контроль, \% & 100 & 100 & 100 \\
\hline
\end{tabular}


Відповідно до розробленого способу [7], зрілі плоди журавлини та глоду миють, інспектують, видаляють плодоніжки та кісточки. Плоди журавлини та глоду окремо бланшують в $1 \ldots .2 \%$ розчині лимонної кислоти за температури $60 \ldots 70^{\circ} \mathrm{C}$ протягом $3 \ldots 6$ хв в універсальному багатофункціональному апараті 3 метою стабілізації поліфенольного комплексу та для пом'якшення тканини. Потім протирають, відділяючи шкірки і кісточки на здвоєній протиральній машині 3 діаметрами сит 1,0..1,2 та 0,4...0,6 мм. Вилучені після протирання шкірку та кісточки з залишками м'якоті відварюють протягом 4...8 хв та 3 метою підвищення виходу готової продукції й зменшення відходів отриману масу повторно протирають на тій же машині.

Яблучне пюре готують за чинною технологічною інструкцією для виробництва плодових і ягідних пюре.

Потім з'єднують масу із журавлини та глоду, протерту масу відвару зі шкірки і кісточок цих ягід, яблучне пюре і перемішують. Купажування плодово-ягідних компонентів здійснювалося відповідно до запропонованого рецептурного співвідношення сировини у композиціях із різним масовим вмістом (табл. 1). У подальшому досліджували кольороутворення багатокомпонентних напівфабрикатів з метою підтвердження збереження їх якості.

Отриману масу попередньо підігрівають до температури $35^{\circ} \mathrm{C}$ та уварюють у вдосконаленому РПА на основі ГПРЕнВТ при температурі $50 \ldots 60^{\circ} \mathrm{C}$ протягом $0,65 \ldots 0,8$ хв до вмісту $25 \ldots 30 \%$ СР. Потім отриману масу розфасовують при температурі $55^{\circ} \mathrm{C}$, закупорюють, стерилізують, маркують. Використання невеликих температур при концентруванні $\left(50 \ldots 60^{\circ} \mathrm{C}\right)$ запобігає значним втратам біологічно цінних речовин і збереженню лікувально-профілактичних властивостей. Також отримані концентровані багатокомпонентні плодово-ягідні пасти в подальшому можна висушувати 3 метою розширення функціонального використання в харчовій промисловості.

Першим етапом було визначення й аналізування кольорових характеристик отриманого багатокомпонентного плодово-ягідного пюре (табл. 2) після купажування компонентів за рецептурою, наведеною в табл. 1.

Таблиия 2. Результат порівняння експериментально отриманих даних спектроскопічного аналізу та цифрової оброки багатокомпонентного плодовоягідного пюре

\begin{tabular}{|c|c|c|c|c|c|c|c|}
\hline \multicolumn{7}{|c|}{ Дані спектроскопічного аналізу } \\
\cline { 1 - 7 } $\begin{array}{c}\text { Зразки компо- } \\
\text { зицій багато- } \\
\text { компонентного } \\
\begin{array}{c}\text { плодово- } \\
\text { ягідного пюре }\end{array}\end{array}$ & \multicolumn{2}{|c|}{$\begin{array}{c}\text { Координати } \\
\text { кольоровості }\end{array}$} & $\begin{array}{c}\text { Довжина } \\
\text { хвилі, що } \\
\text { домінує }\end{array}$ & $\begin{array}{c}\text { Яскра- } \\
\text { вість }\end{array}$ & $\begin{array}{c}\text { Чистота } \\
\text { кольору }\end{array}$ & $\begin{array}{c}\text { Візуальна } \\
\text { характеристика } \\
\text { кольору зразків }\end{array}$ \\
\hline 1 & 2 & 3 & 4 & 5 & 6 & 7 & 8 \\
\hline Зразок 1а & 4,5 & 2,95 & 0,75 & 610,8 & 35,9 & 76,4 & $\begin{array}{c}\text { червонувато- } \\
\text { помаранчевий }\end{array}$ \\
\hline Зразок 1б & 3,79 & 2,39 & 0,75 & 614,5 & 34,5 & 70,7 & $\begin{array}{c}\text { червонувато- } \\
\text { помаранчевий }\end{array}$ \\
\hline Зразок 1в & 4,73 & 3,03 & 0,78 & 616,1 & 37,6 & 78,1 & $\begin{array}{c}\text { червонувато- } \\
\text { помаранчевий }\end{array}$ \\
\hline
\end{tabular}




\begin{tabular}{|c|c|c|c|c|c|c|c|c|}
\hline \multicolumn{10}{|c|}{ Дані аналізу цифрового методу обробки } \\
\hline 1 & 2 & 3 & 4 & 5 & 6 & 7 & 8 \\
\hline Зразок 1а & 4,6 & 2,8 & 0,7 & 610 & 36 & 76 & $\begin{array}{c}\text { червонувато- } \\
\text { помаранчевий }\end{array}$ \\
\hline Зразок 16 & 3,9 & 2,4 & 0,7 & 614 & 34 & 71 & $\begin{array}{c}\text { червонувато- } \\
\text { помаранчевий }\end{array}$ \\
\hline Зразок 1в & 4,2 & 3,6 & 0,7 & 616 & 38 & 78 & $\begin{array}{c}\text { червонувато- } \\
\text { помаранчевий }\end{array}$ \\
\hline
\end{tabular}

За даними спектроскопічного аналізу довжина хвилі, що домінуе в зразку пюре 1a, становить 610,8 нм і характеризує червонувато-помаранчевий колір 3 чистотою кольорового тону - 76,4\%. Для зразків 16 та 1в - 614,5 і 616,1 нм відповідно. Для зразка 16 значення чистоти тону $(70,7$ \%) відповідає червонувато-помаранчевому кольору. Чистота тону $78,1 \%$ у зразку 1в характеризує червонувато-помаранчевий колір.

Другим етапом стало порівняння отриманих результатів спектроскопії та цифрового методу аналізу дослідних зразків багатокомпонентних плодовоягідних паст.

Аналізування отриманих спектрів віддзеркалення композицій багатокомпонентних паст показало, що мінімальна складова синього кольору $(z)$ для зразка пасти $1 \mathrm{a}-0,49$, а композиції 16 та 1в характеризуються значеннями 0,77 і 0,53 відповідно (табл. 3).

Таблиия 3. Результат порівняння експериментально отриманих даних спектроскопічного аналізу та цифрової оброки багатокомпонентних плодово-ягідних паст

\begin{tabular}{|c|c|c|c|c|c|c|c|}
\hline \multicolumn{8}{|c|}{ Дані спектроскопічного аналізу } \\
\hline $\begin{array}{c}\text { Дослідні зразки } \\
\text { композицій бага- } \\
\text { токомпонентних }\end{array}$ & \multicolumn{3}{|c|}{$\begin{array}{l}\text { Координати } \\
\text { кольоровості }\end{array}$} & $\begin{array}{l}\text { Довжина } \\
\text { хвилі, що } \\
\text { домінує }\end{array}$ & $\begin{array}{c}\text { Яскра- } \\
\text { вість }\end{array}$ & $\begin{array}{l}\text { Чистота } \\
\text { кольору }\end{array}$ & \multirow{2}{*}{$\begin{array}{c}\text { Візуальна характе- } \\
\text { ристика кольору } \\
\text { зразків }\end{array}$} \\
\hline $\begin{array}{c}\text { Плодово-ягідних } \\
\text { паст } \\
\end{array}$ & $x$ & $y$ & $z$ & $\lambda_{\text {нм }}$ & $T, \%$ & $P, \%$ & \\
\hline Зразок 1а & 3,05 & 2,02 & 0,49 & 610,0 & 36,1 & 77,6 & $\begin{array}{l}\text { червонувато- } \\
\text { помаранчевий }\end{array}$ \\
\hline Зразок 16 & 2,12 & 2,00 & 0,77 & 613,4 & 34,7 & 64,0 & $\begin{array}{l}\text { червонувато- } \\
\text { помаранчевий }\end{array}$ \\
\hline Зразок 1в & 3,17 & 2,04 & 0,53 & 614,1 & 37,7 & 78,9 & $\begin{array}{c}\text { червоно- } \\
\text { помаранчевий }\end{array}$ \\
\hline \multicolumn{8}{|c|}{ Дані аналізу цифрового методу обробки } \\
\hline Зразок 1a & 3,0 & 2,0 & 0,5 & 610,0 & 36,0 & 76,0 & $\begin{array}{l}\text { червонувато- } \\
\text { помаранчевий }\end{array}$ \\
\hline Зразок 16 & 2,0 & 2,5 & 0,8 & 612,0 & 35,0 & 65,0 & $\begin{array}{l}\text { червонувато- } \\
\text { помаранчевий }\end{array}$ \\
\hline Зразок 1в & 3,0 & 2,0 & 0,5 & 613,0 & 38,0 & 78,0 & $\begin{array}{c}\text { червоно- } \\
\text { помаранчевий }\end{array}$ \\
\hline
\end{tabular}

Установлена довжина хвилі, що переважає в зразку пасти 1а, дорівнює 610 нм, а чистота тону - 77,8\%. Для пасти 16 - довжина хвилі становить 613,4 нм, чистота тону $-64,6 \%$, а для зразка 1в - 614,1 нм, чистота тону 78,1. Усі дослідні композиції паст мали червонувато-помаранчевий колір. 
Порівняння візуальних характеристик кольору зразків (табл. 2, 3) підтверджує збереження кольорів у пюре до термічної обробки та концентрованих паст. Збереження кольорових характеристик під час концентрування підтверджує мінімальні фізико-хімічні зміни при тепловій обробці та максимальне збереження БАР і лікувально-профілактичних властивостей кінцевого продукту - пасти.

Третім етапом було порівняння отриманих результатів спектроскопії та цифрового методу аналізу дослідних зразків сушених багатокомпонентних плодово-ягідних паст (табл. 4), виготовлених відповідно до попередньо запропонованих рецептурних співвідношень.

Сушіння композицій багатокомпонентних плодово-ягідних паст із вмістом 28...30\% СР здійснювали у вальцьовій ІЧ-сушарці на основі ГПРЕнВТ за низькотемпературного режиму $\left(45^{\circ} \mathrm{C}\right)$ й товщини шару сировини на рифленому барабані - 1 мм. Запропонований апарат має подрібнювальний механізм, розташований у розвантажувальній частині сушарки, що дає змогу отримувати порошкоподібну фракцію сушеного напівфабрикату. Процес IЧсушіння здійснювався до досягнення кінцевого вологовмісту напівфабрикату на рівні $4 . . .6 \%$, з подальшим фасуванням у світловіддзеркалювальні герметичні поліетиленові пакети.

Масову частку сухих речовин визначали за ГОСТ 28561-90.

Таблиия 4. Результат порівняння експериментально отриманих даних спектроскопічного аналізу та цифрової оброки сушених багатокомпонентних плодово-ягідних паст

\begin{tabular}{|c|c|c|c|c|c|c|c|}
\hline \multicolumn{7}{|c|}{ Дані спектроскопічного аналізу } \\
\hline $\begin{array}{c}\text { Зразки сушених } \\
\text { багатокомпонен- } \\
\text { тних плодово- } \\
\text { ягідних паст }\end{array}$ & \multicolumn{2}{|c|}{ Координати кольоровості } & $\begin{array}{c}\text { Довжина } \\
\text { хвилі, що } \\
\text { домінує }\end{array}$ & $\begin{array}{c}\text { Яскра- } \\
\text { вість }\end{array}$ & $\begin{array}{c}\text { Чистота } \\
\text { кольору }\end{array}$ & $\begin{array}{c}\text { Візуальна } \\
\text { характеристика } \\
\text { кольору зразків }\end{array}$ \\
\cline { 2 - 9 } Зразок 1a & 0,615 & 0,387 & 0,271 & 498,0 & 30,4 & 34,7 & $\begin{array}{c}\text { синювато- } \\
\text { пурпурний }\end{array}$ \\
\hline Зразок 16 & 0,606 & 0,435 & 0,305 & 620,5 & 32,3 & 34,8 & червоний \\
\hline Зразок 1в & 0,611 & 0,408 & 0,284 & 589,4 & 33,1 & 34,6 & $\begin{array}{c}\text { синювато- } \\
\text { червоний }\end{array}$ \\
\hline \multicolumn{7}{|c|}{ Дані аналізу цифрового методу обробки } \\
\hline Зразок 1а & 0,6 & 0,4 & 0,3 & 497,0 & 30,0 & 34,2 & $\begin{array}{c}\text { синювато- } \\
\text { пурпурний }\end{array}$ \\
\hline Зразок 1б & 0,5 & 0,4 & 0,3 & 619,0 & 32,0 & 35,0 & червоний \\
\hline Зразок 1в & 0,6 & 0,5 & 0,3 & 590,0 & 33,0 & 34,2 & $\begin{array}{c}\text { синювато- } \\
\text { червоний }\end{array}$ \\
\hline
\end{tabular}

Характерною довжиною хвилі для зразка сушеної трикомпонентної плодово-ягідної пасти 1а є 498 нм, що відповідає синювато-пурпурному кольору 3 чистотою тону $34,7 \%$. Зразки 16 та 1в відповідно мають довжини 620,5 та 589,4 нм. Для зразка 16 значення чистоти тону $(34,8 \%)$ відповідає червоному кольору. Зразок 1в характеризується синювато-червоним кольором, оскільки має чистотою тону $34,6 \%$.

Порівнюючи візуальні характеристики кольорів, а саме: яскравість і чистоту тону зразків паст до та після сушіння (табл. 3-4), можна зробити виснов- 
ки, що яскравість дещо слабшає (в межах 2..6\%). Чистота кольору, у свою чергу, зменшується фактично вдвічі, що пояснюється усушуванням маси сировини та проведенням більшої кількості теплових обробок, хоча й досягається привабливий візуальний колір зразків для споживача.

Аналізування порівняльних таблиць (2-4) підтверджує подальшу ефективність використання цифрового методу аналізу кольорових характеристик під час будь-якого доступного для фотографування технологічного процесу. Розбіжності отриманих результатів порівняльного аналізування кольорових параметрів дослідних зразків, отриманих під час спектрального аналізу та запропонованого цифрового методу, становлять менше 5\%, що в межах експериментальної похибки. При цьому запропонований метод цифрового аналізування кольору не лише для плодово-ягідних композицій, а й харчових продуктів у цілому забезпечує мобільність і портативність аналізування з короткотривалою обробкою отриманих цифрових даних та одночасного представлення отриманих результатів в якісні кольорові параметри.

Завершальним етапом досліджень 3 підтвердження якості отримуваних напівфабрикатів є проведення сенсорного оцінювання отриманих кінцевих продуктів, а саме: багатокомпонентних плодово-ягідних паст (табл. 5) і сушених порошкоподібних напівфабрикатів на їх основі (табл. 6) відповідно до методики Свропейської організації за контролем якості харчових продуктів.

Аналіз даних стосовно результатів оцінювання багатокомпонентних плодово-ягідних паст (табл. 5) підтвердив найкращу якість багатокомпонентної природної пасти 3 введенням у 60-відсоткове яблучне пюре журавлини в кількості $30 \%$, глоду 10\% (зразок 1а) до загальної маси сировини. Уведення журавлини і глоду у великих кількостях негативно впливає на смакові якості виробів, у менших - призводить до зниження харчової цінності і погіршення органолептичних характеристик продукту.

За результатами оцінювання найкращу якість сушених трикомпонентних плодово-ягідних паст має зразок 1а з вмістом 60\% яблучної сировини, 30\% журавлини та 10\% глоду. Уведення у великих або менших кількостях журавлини і глоду призводило до зміни органолептичних характеристик продукту, а отже, й харчової цінності в цілому.

Таблиця 5. Результати експертного оцінювання показників якості багатокомпонентних плодово-ягідних паст

\begin{tabular}{|c|c|c|c|c|c|c|}
\hline \multirow{2}{*}{ Приклад } & \multicolumn{5}{|c|}{$\begin{array}{c}\text { Показники якості багатокомпонентних } \\
\text { плодово-ягідних паст, бал }\end{array}$} & \multirow{2}{*}{$\begin{array}{l}\text { Загальна } \\
\text { оцінка, бал }\end{array}$} \\
\hline & $\begin{array}{l}\text { Зовнішній } \\
\text { вигляд }\end{array}$ & Консистенція & Колір & Смак & Запах & \\
\hline \multicolumn{7}{|c|}{ Зразки композицій багатокомпонентних плодово-ягідних паст } \\
\hline зразок 1a & 10 & 15 & 9 & 10 & 5 & 49 \\
\hline зразок 16 & 9 & 14 & 9 & 9 & 5 & 46 \\
\hline зразок 1в & 9 & 14 & 8 & 8 & 4 & 43 \\
\hline $\begin{array}{c}\text { Прототип (паста } \\
3 \text { яблука, айви та } \\
\text { бузини) }\end{array}$ & 10 & 14 & 9 & 10 & 5 & 48 \\
\hline
\end{tabular}


Таблиия 6. Результати експертного оцінювання показників якості сушених багатокомпонентних плодово-ягідних паст

\begin{tabular}{|c|c|c|c|c|c|c|}
\hline \multirow{2}{*}{ Приклад } & \multicolumn{5}{|c|}{ Показники якості сушених багатокомпонентних } & \multirow{2}{*}{$\begin{array}{c}\text { Загальна } \\
\text { оцінка, бал }\end{array}$} \\
\cline { 2 - 6 } & $\begin{array}{c}\text { Зовнішній } \\
\text { вигляд }\end{array}$ & Консистенція & Колір & Смак & Запах & \\
\hline \multicolumn{7}{|c|}{ Сушені багатокомпонентні плодово-ягідні пасти } \\
\hline зразок 1а & 10 & 15 & 9 & 10 & 5 & 49 \\
\hline зразок 1б & 9 & 14 & 8 & 9 & 5 & 45 \\
\hline зразок 1в & 9 & 13 & 7 & 8 & 4 & 41 \\
\hline $\begin{array}{c}\text { Прототип } \\
\text { (сушена триком- } \\
\text { понентна пло- } \\
\text { дово-ягідна паста } \\
\begin{array}{c}\text { з яблука, айви та } \\
\text { бузини чорної) }\end{array}\end{array}$ & 10 & 14 & 9 & 9 & 5 & 47 \\
\hline
\end{tabular}

\section{Висновки}

Отже, аналіз наведених результатів досліджень кольорових характеристик сушених багатокомпонентних плодово-ягідних паст залежно від їх рецептурного співвідношення за розробленим способом виробництва із використанням низькотемпературного процесу попереднього концентрування в РПА та сушіння у вальцьовій ІЧ-сушарці на основі ГПРЕнВТ дав змогу визначити довжини хвиль, що переважають, та чистоти тонів для концентрованих паст із вмістом $25 \ldots 30 \%$ СР і сушених із вмістом $4 \ldots 6 \% \mathrm{CP}$.

Порівнюючи візуальні характеристики кольорів, а саме: яскравість та чистоту тону зразків паст до обробки та ІЧ-сушіння, можна стверджувати, що відбувається незначна зміна яскравості в межах $2 . .6 \%$. Зменшення чистоти кольору майже вдвічі пояснюється усушуванням маси сировини та проведенням більшої кількості теплових обробок, хоча й досягається привабливий візуальний колір зразків для споживача.

Підтверджено подальшу ефективність використання цифрового методу аналізу кольорових характеристик під час будь-якого доступного для фотографування технологічного процесу.

За результатами оцінювання якості сушених багатокомпонентних плодово-ягідних паст певну перевагу має напівфабрикат із таким співвідношення компонентів: яблуко, журавлина, глід - 60:30:10 (зразок 1а). Уведення у великих або менших кількостях журавлини і глоду призводило до зміни органолептичних характеристик продукту, а отже, й харчової цінності в цілому.

Запропоновані пастоподібні та сушені багатокомпонентні плодово-ягідні пасти рекомендовано до застосування в раціонах харчування як самостійний продукт, а також для виробництва борошняної кулінарної продукції, безалкогольних і горілчаних напоїв, кондитерських і хлібобулочних виробів.

Подальші дослідження планується спрямувати у напрямку визначення оптимальних режимів попередньої теплової обробки рослинної сировини 3 метою підвищення якості отримуваних напівфабрикатів та зменшення відходів. 


\section{Лiтература}

1. Елисеева Л.Г., Грибова Н.А. Анализ экономической эффективности перерабатывающих предприятий плодово-ягодного сырья на основе внедрения инновационных ресурсосберегающих технологий. Экономика: вчера, сегодня, завтра. 2016. № 9. С. 92-101.

2. Снежкин Ю.Ф., Боряк Л.А., Хавин А.А. Энергосберегающие теплотехнологии производства пищевых порошков из вторичных сырьевых ресурсов: монография. Киев: Наукова думка, 2004. $228 \mathrm{c}$.

3. Глухова Е.Н., Пилипенко Т.В. Изучение качества функциональных добавок на основе растительного сырья. Проблемы экономики и управления в торговле и промышленности. 2014. № 51. С. $90-94$.

4. Пат. на корисну модель 124046 Україна, МПК G01N 33/02 G01J 3/00. Спосіб визначення кольору харчових продуктів / Черевко О.І., Михайлов В.М., Загорулько А.М., Загорулько О.С., Ляшенко Б.В., Черв'якова В.А., Коржавих Д.К.; Заявник та патентовласник Харк. держ. ун-т харч. та торг. № u 201712264; заявл. 11.12.2017; опубл. 12.03.2018, Бюл. № 5.

5. Пат. на корисну модель 124573 Україна, B01D 1/22 (2006.01), H05B 3/36(2006.01). Роторний випарник / Черевко О.І., Кіптела Л.В., Загорулько О.Є., Загорулько А.М., Ляшенко Б.В.; Заявник та патентовласник Харк. держ. ун-т харч. та торг. № u201711824; заявл. 04.12.2017; опубл. 10.04.2018, Бюл. № 7.

6. Пат. на корисну модель 119166 Україна, МПК В01D1/22. Вальцьова ІЧ-сушарка для сушіння природних паст (пюре) у порошкоподібні напівфабрикати / Загорулько А.М., Загорулько О.С., Дяченко Н.В., Гончаренко В.А.; заявник та патентовласник Харк. держ. ун-т харч. та торг. № u 201703857 ; заявл. 19.04.2017 ; опубл. 11.09.2017, Бюл. № 17. 5 с.

7. Пат. на корисну модель 119164 Україна, МПК A23L 21/10. Спосіб виробництва плодово-ягідної пасти / Загорулько А. М., Загорулько О. Є., Філоненко А.О. ; заявник та патентовласник Харк. держ. ун-т харч. та торг. № u 201703852 ; заявл. 19.04.2017 ; опубл. 11.09.2017, Бюл. № 4.4 c. 